\title{
ANALISIS DOMINASI PENGGUNAAN LAHAN KEKOTAAN DAN KEDESAAN DI KECAMATAN KEMBARAN
}

\author{
Sakinah Fathrunnadi Shalihati ${ }^{13}$, Sutomo ${ }^{2}$, Suwarno ${ }^{3}$ \\ 1,2,3Staf Pengajar Pendidikan Geografi FKIP Universitas Muhammadiyah Purwokerto \\ Jl. Raya Dukuh Waluh PO.BOX. 202 Purwokerto 53182 Telp. (0281) 636751 \\ 1geografiump@gmail.com, 2pemangkulongsor@yahoo.com, 3sakinahf@ump.ac.id
}

\begin{abstract}
Abstrak. Kecamatan Kembaran merupakan salah satu kecamatan di Kabupaten Banyumas yang sedang mengalami perkembangan wilayah yang cukup pesat. Seperti yang telah ditemukan dalam penelitian Sutomo dan Shalihati Tahun 2014 menunjukkan bahwa Desa Dukuh Waluh salah satu desa di Kecamatan Kembaran mengalami transformasi wilayah yang tinggi nampak dari terjadinya perubahan jumlah infrastruktur yang semakin meningkat selama 10 tahun terakhir. Jumlah infrastruktur yang semakin meningkat tentu memberikan dampak terjadinya penambahan lahan terbangun diwilayah tersebut. Untuk itu penelitian yang diusulkan saat ini merupakan tindak lanjut dari penelitian tersebut, yang diharapkan untuk mengetahui sejauh mana dominasi penggunaan lahan kekotaan dan kedesaan serta termasuk apa saja desa-desa di Kecamatan Kembaran dalam ketentuan subzone Urban/Ural/Rural menurut Yunus (2000).

Metode dalam penelitian ini adalah analisis data primer dan sekunder dengan menggunakan Sistem Informasi Geografi (SIG). Menggunakan teknik analisis kualitatif untuk Menggunakan teknik analisis kualitatif untuk: 1. Analisis dominasi penggunaan lahan kekotaan dan kedesaan di Kecamatan Kembaran, 2. Analisis kategori desa-desa di Kecamatan Kembaran dalam ketentuan subzone Urban/Ural/Rural menurut Yunus (2000).

Hasil penelitian menunjukkan dominasi penggunaan lahan kekotaan dan kedesaan di Kecamatan Kembaran menunjukkan bahwa terdapat desa dengan dominasi penggunaan lahan kekotaan mencapai $48.06 \%$ dari luas wilayah desanya,, yaitu Desa Dukuh Waluh, namun ada pula desa dengan penggunaan lahan kekotaan $16.29 \%$ dari luas wilayah desanya yaitu Desa Sambeng Kulon. Sedangkan dari hasil meninjau persentase penggunaan lahan kekotaan dan kedesaan sekaligus persentase jarak dari daerah Kota Purwokerto ke desa-desa di Kecamatan Kembaran, maka menurut Model Segitiga Penggunaan Lahan Desa-Kota masuk pada subzone Urban Fringe.
\end{abstract}

Kata Kunci : Penggunaan Lahan, Kekotaan, Kedesaan.

\section{PENDAHULUAN}

Penggunaan lahan merupakan bagian yang tidak dapat dipisahkan dari kehidupan manusia, gambaran nyata mengenai penggunaan lahan disuatu wilayah merupakan hasil bentuk representasi kegiatan manusia terhadap lahan. Menurut Malingreau (1977) penggunaan lahan adalah segala campur tangan manusia, baik secara permanen maupun secara siklus terhadap suatu kelompok sumberdaya alam dan sumber daya buatan, yang secara keseluruhan disebut lahan, dengan tujuan untuk mencukupi kebutuhan-kebutuhan manusia baik secara kebendaan maupun spiritual ataupun kedua-duanya.

Penggunaan lahan inilah yang kemudian menjadikan dasar untuk mengkategorikan suatu tempat tersebut dapat dikatakan sebagai kota atau desa, sesuai dengan pernyataan Yunus (1994) bahwa secara umum unsur-unsur 
morfologi kota berkisar antara karakteristik bangunan, pola jalan dan penggunaan lahan dan unsur-unsur inilah yang paling sering digunakan untuk mengenali suatu daerah secara, morfologis, kekotaan atau bukan.

Penggunaan lahan sebagai salah satu produk kegiatan manusia dipermukiman bumi memang menunjukkan variasi yang sangat besar, baik didalam kota lokal maupun di dalam kota regional. Pemahaman bentuk-bentuk penggunaan lahan yang mewarnai daerah terbangun (built up area), daerah peralihan kota-desa serta daerah kedesaan sendiri merupakan suatu hal yang prinsipil untuk melakukan diferensiasi struktur keruangannya. Sedangkan untuk membedakan jenis penggunaan lahan kekotaan dan penggunaan lahan kedesaan, pada umumnya keterkaitan jenis-jenis tersebut dengan lahan pertanian menjadi fokus utamanya (Yunus, 2000).

Kecamatan Kembaran merupakan salah satu kecamatan di Kabupaten Banyumas yang sedang mengalami perkembangan wilayah yang cukup pesat. Seperti yang telah ditemukan dalam penelitian Sutomo dan Shalihati Tahun 2014 menunjukkan bahwa Desa Dukuh Waluh salah satu desa di Kecamatan Kembaran mengalami transformasi wilayah yang tinggi nampak dari terjadinya perubahan jumlah infrastruktur yang semakin meningkat selama 10 tahun terakhir. Jumlah infrastruktur yang semakin meningkat tentu memberikan dampak terjadinya penambahan lahan terbangun diwilayah tersebut. Hadirnya penelitian ini merupakan tindak lanjut dari penelitian tersebut, yang diharapkan untuk mengetahui sejauh mana dominasi penggunaan lahan kekotaan dan kedesaan serta termasuk apa saja desa-desa di Kecamatan Kembaran dalam ketentuan subzone Urban/Ural/Rural menurut Yunus (2000).

\section{METODE PENELITIAN}

Metode penelitian ini bersifat diskriptif kualitatif, bertujuan mendiskripsikan dengan tulisan secara tersistematis dan menggunakan kalimat yang mudah menggambarkan keadaan nyata dari hasil penelitian yang diperoleh. Sedangkan metode dalam penelitian ini adalah analisis data primer dan sekunder serta menggunakan SIG dengan bantuan software Arc GIS 9.

Menggunakan teknik analisis kualitatif untuk: 1. Analisis dominasi penggunaan lahan kekotaan dan kedesaan di Kecamatan Kembaran, 2. Analisis kategori desa-desa di Kecamatan Kembaran dalam ketentuan subzone Urban/Ural/Rural menurut Yunus (2000).

\section{Populasi dan Sampel}

Populasi penelitian ini adalah seluruh desa di Kecamatan Kembaran yang berjumlah 16 desa menurut Kecamatan Kembaran dalam Angka 2016 (BPS Kabupaten Banyumas, 2016).

Dikarenakan adanya keterbatasan waktu penelitian, untuk itu ruang lingkup yang diteliti dalam penelitian ini dibatasi, dari seluruh desa di Kecamatan Kembaran yang berjumlah 16 desa diambil 3 desa sebagai sampel. Dalam menentukan sampel menggunakan teknik area sampling.

\section{Alat dan Bahan}

Peralatan yang digunakan dalam penelitian ini adalah seperangkat alat tulis dan kamera yang akan digunakan untuk pencatatan saat melakukan observasi dalam rangka pengecekan penggunaan lahan antara yang diperoleh dari data citra dengan kenyataannya dilapangan. Alat pendukung lainnya berupa Global Positioning System (GPS) yang digunakan untuk pengambilan koordinat data sampling penggunaan lahan yang nyata dilapangan. 
Sedangkan peralatan yang digunakan dalam pembuatan peta adalah seperangkat komputer yang dilengkapi software SIG berupa ArcGis 9 dengan kapasitas hardisk 250 GB dan processor dual core, yang akan digunakan dalam pengolahan data presentase penggunaan lahan kekotaan, presentase penggunaan lahan kedesaan, dan presentase jarak dari lahan kekotaan utama ke lahan kedesaan utama di Kecamatan Kembaran.

Bahan yang digunakan dalam penelitian ini adalah sebagai berikut:

a. Peta batas administrasi di Kecamatan Kembaran.

b. Data penggunaan lahan yang diperoleh dari data penginderaan jauh citra Google Earth di wilayah Kecamatan Kembaran.

c. Data hasil observasi kesesuaian sampel penggunaan lahan Kecamatan Kembaran dari data citra Google Earth dengan kenyataannya dilapangan.

d. Data statistik kependudukan Kecamatan Kembaran dalam Angka Tahun 2016.

\section{Sumber dan Teknik Penentuan Data}

\section{a. Data Primer dan Data Skunder}

Data primer penelitian ini adalah data hasil observasi kesesuaian sampel penggunaan lahan Kecamatan Kembaran dari data citra Google Earth dengan kenyataannya dilapangan. Sedangkan Data Sekunder terdiri dari;

Data Sekunder penelitian ini meliputi:

1) Peta batas administrasi di Kecamatan Kembaran.

2) Data penggunaan lahan yang diperoleh dari data penginderaan jauh citra Google Earth di wilayah Kecamatan Kembaran.

3) Data statistik kependudukan Kecamatan Kembaran dalam Angka Tahun 2016. b. Teknik Pengumpulan Data

\section{1) Observasi Lapangan}

Observasi digunakan sebagai teknik pengumpulan data dengan cara melakukan pengamatan, pencatatan langsung secara sistematik dan pengambilan koordinat lokasi sampel penggunaan lahan Kecamatan Kembaran.

Hasil informasi yang diperoleh dari observasi sampel penggunaan lahan di Kecamatan Kembaran digunakan untuk dasar kesesuaiaan antara penggunaan lahan yang diperoleh dari data citra dengan kenyataannya dilapangan.

2) Intepretasi Citra Satelit

Intepretasi citra satelit dari data penginderaan jauh dilakukan untuk mengidentifikasi penggunaan lahan yang ada di Kecamatan Kembaran menggunakan teknik intepretasi secara visual.

3) Dokumentasi

Dokumentasi dengan menggunakan kamera saat observasi bertujuan untuk mengetahui secara visual kondisi objek penelitian ini, dan sebagai bukti fisik kegiatan penelitian. Penelitian ini juga melakukan pengumpulan dokumentasi lainnya yang menunjang penelitian yaitu data statistik kependudukan Kecamatan Kembaran meliputi data jumlah penduduk, pertumbuhan penduduk, mata pencaharian pada wilayah administrasi.

\section{Teknik Pengolahan Data}

Pengolahan data penelitian ini menggunakan SIG dengan bantuan software ArcGis 9. SIG merupakan 
rangkaian kegiatan sistem yang tersistematis, dimulai dari adanya pengguna, perangkat keras, perangkat lunak berupa software SIG dan managemen spasial yang berfungsi untuk mengatur input, proses dan output. SIG dengan mudah mengkombinasikan data spasial dengan data atribut sehingga menampilkan penjelasan yang komprehensif dan bernilai keruangan.

\section{Teknik Analisis Data}

\section{a. Analisis Dominasi Penggunaan} Lahan Kekotaan Dan Kedesaan Di Kecamatan Kembaran

Terlebih dahulu diawali dengan pembuatan peta penggunaan lahan di Kecamatan Kembaran dengan memanfaatkan SIG pada software ArcGis 9. Peta penggunaan lahan bersumber dari citra satelit Google Eart dan sampel pengecekan penggunaan lahan di lapangan, sedangkan batas penggunaan lahan yang dipetakan mengikuti batas administrasi desa.

Langkah pembuatan peta tersebut meliputi sebagai berikut: 1 . Input data SIG berupa data spasial peta batas administrasi, peta penggunaan lahan dari citra satelit dan data pengecekan penggunaan lahan dilapangan, 2. Tahap proses terdapat 2 kegiatan yaitu digitasi batas administrasi desa dan penggunaan lahan pada desa, selanjutnya tabulasi data atribut penggunaan lahan 3. Hasil output pada layout adalah peta penggunaan lahan dan data tabel luasan penggunaan lahan pada masingmasing desa di Kecamatan Kembaran.

Dari hasil output tersebut kemudian dianalisis secara diskriptif mengenai persentase penggunaan lahan kekotaan dan kedesaan pada masing-masing desa sampel. Adapun penggunaan lahan kekotaan adalah bangunan/permukiman atau terkait dengan kegiatan industri dan permukiman, sedangkan penggunaan lahan kedesaan adalah sawah, kebun, tegalan atau terkait dengan kegiatan pertanian (Yunus, 2000).

b. Analisis kategori desa-desa di Kecamatan Kembaran dalam ketentuan subzone Urban/ Ural/ Rural menurut Yunus (2000).

Setelah diketahui penggunaan lahan yang mendominasi pada desadesa sampel penelitian dalam bentuk persentase penggunaan lahan kekotaan dan kedesaan, selanjutnya masing-masing desa sampel diklasifikasikan apakah termasuk Urban/Urral ataukah Rural menurut Yunus (2000) dalam Model Segitiga Penggunaan Lahan Desa-Kota berikut ini: 


\section{Jurnal}

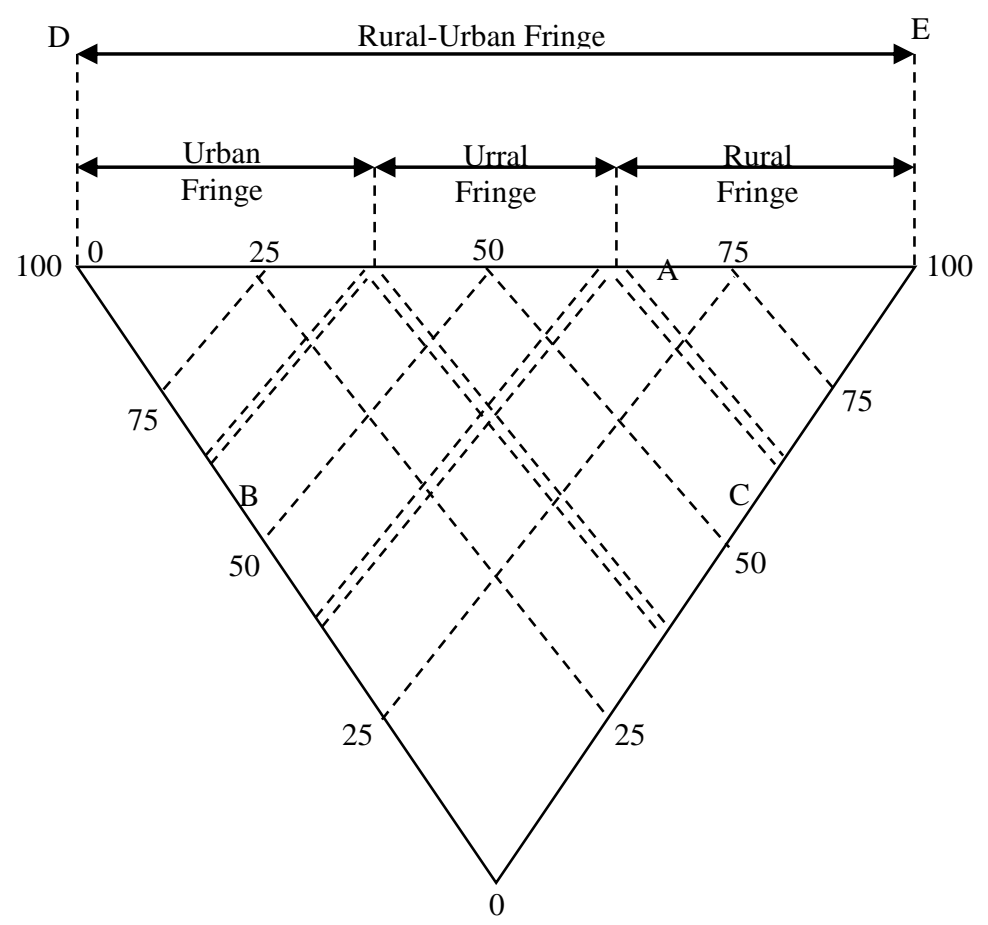

Keterangan:

A : Persentase jarak dari daerah kota ke daerah desa

B : Persentase penggunaan lahan kekotaan

$\mathrm{C}$ : Persentase penggunaan lahan kedesaan

D : Batas dari area bangunan kekotaan

$\mathrm{E}:$ Batas dari area kedesaan 


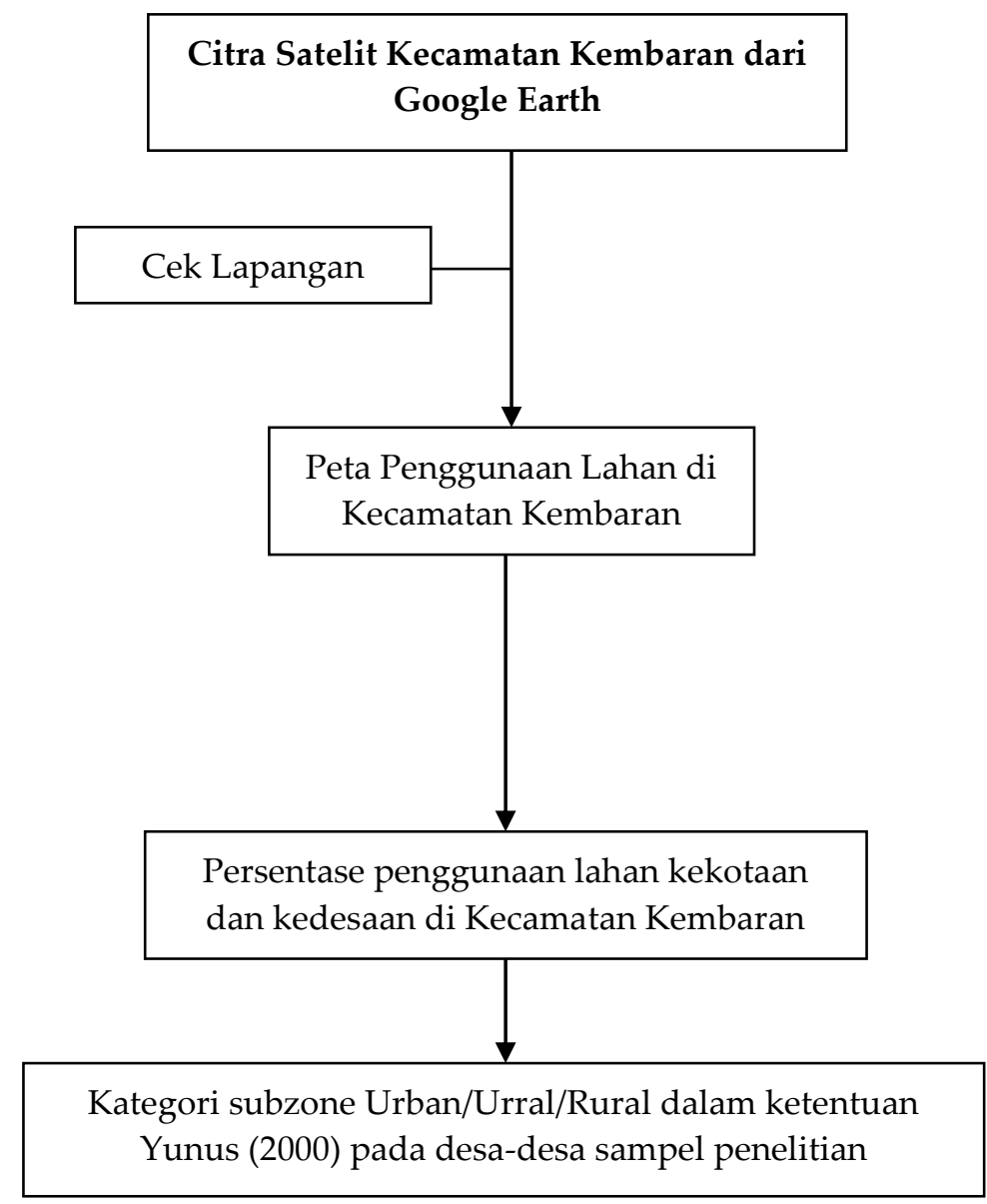

Diagram 2. Alur Pelaksanaan Penelitian

\section{HASIL DAN PEMBAHASAN}

\section{Deskripsi Wilayah Penelitian}

Kecamatan Kembaran secara administratif berada di Timur Laut dari Kota Purwokerto. Pada bagian Utara Kecamatan Kembaran berbatasan dengan Kecamatan Sumbang, Timur berbatasan dengan Kabupaten Purbalingga, Selatan berbatasan dengan Kecamatan Sokaraja dan di sebelah Barat berbatasan dengan Kecamatan Purwokerto Timur (Peta Digital Rupa Bumi Indonesia, 2000)

Menurut Badan Pusat Statistik (2016) Kecamatan Kembaran memiliki topografi permukaan daratan yang relatif datar, dengan luas wilayah $\pm 25,92 \mathrm{~km}^{2}$ atau 2.591,776 Ha. Desa yang memiliki wilayah terluas di Kecamatan Kembaran adalah
Desa Pliken dengan luas wilayah $3,4 \mathrm{~km}^{2}$ atau sekitar 13,1 \% dari luas wilayah Kecamatan Kembaran, lebih jelasnya Nampak pada Gambar 1.

Adapun penggunaan lahan Kecamatan Kembaran tercatat 1.770,89 Ha Tanah Sawah, 684,99 Tanah Kering dan 135,90 digunakan untuk lain-lain. Penggunaan lahan Kecamatan Kembaran didominasi tanah sawah, hal ini sangat dipengaruhi

oleh kondisi iklimnya, dimana Kecamatan Kembaran merupakan salah satu kecamatan yang mempunyai curah hujan cukup tinggi disebabkan berdekatan dengan Gunung Slamet yang merupakan salah satu chatment area di Jawa Tengah bagian Barat. Menurut Data Statistik Kecamatan Kembaran dalm 


\section{Jurnal}

periode Januari sampai dengan Desember 2015, curah hujan tertinggi terjadi pada bulan Maret yaitu $2.012 \mathrm{~mm}$, sedangkan pada bulan Agustus tidak terjadi hujan.

Secara administrasi, Kecamatan Kembaran terbagi menjadi 16 desa, dan untuk mempermudah koordinasi penduduk di masing-masing desa dibagi menjadi beberapa rukun warga (RW) dan dibawahnya dibagi lagi menjadi beberapa rukun tetangga

(RT).

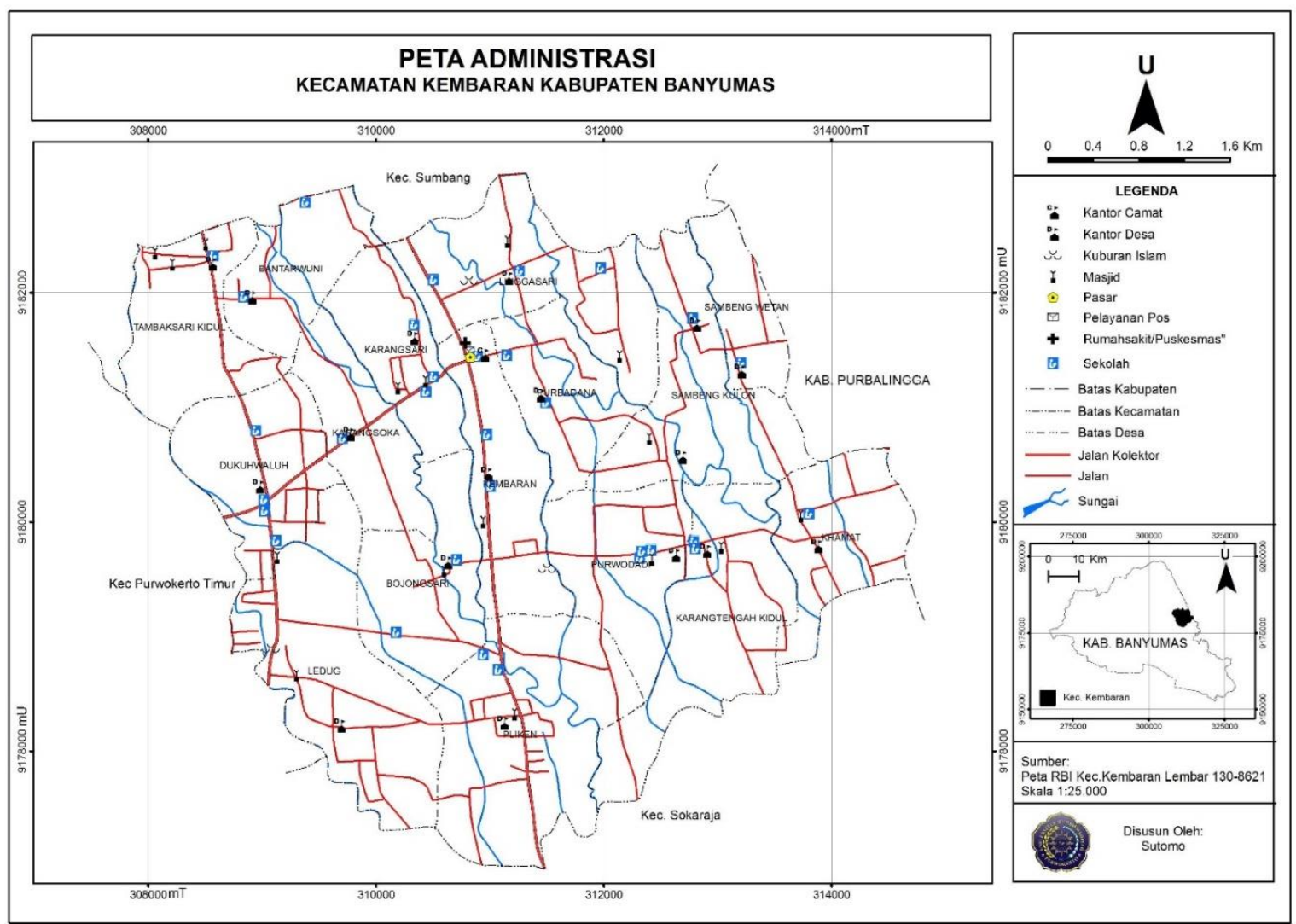

Gambar 1. Peta Administrasi Kecamatan Kembaran Kabupaten Banyumas

Kecamatan Kembaran terdiri dari 76 rukun warga dan 424 rukun tetangga dengan jumlah penduduk 79.166 orang dan penduduk terbanyak yaitu $12 \mathrm{RW}, 75$ RT dan 14.439 orang penduduk.

Dari hasil proyeksi penduduk akhir Tahun 2016 berdasarkan laju pertumbuhan penduduk, jumlah penduduk Kecamatan Kembaran adalah
79.166 orang yang terdiri dari 39.686 lakilaki dan 39.480 perempuan. Dengan luas wilayah sekitar 25,92 kilometer persegi yang didiami oleh 79.166 orang maka ratarata tingkat kepadatan penduduk Kecamatan Kembaran adalah sebanyak 3.054 orang per kilometer persegi, secara jelas ditampilkan pada Tabel 1.

Tabel 1. Penduduk dan Kepadatan Penduduk menurut Desa Tahun 2015

\begin{tabular}{|c|l|r|r|r|}
\hline No. & \multicolumn{1}{|c|}{ Desa } & Jumlah Penduduk & Luas Wilayah & Kepadatan Penduduk \\
\hline 1. & Ledug & 14.439 & 2,20 & $6.563,18$ \\
\hline 2. & Pliken & 8.282 & 3,40 & $2.435,88$ \\
\hline
\end{tabular}




\begin{tabular}{|c|l|r|r|r|}
\hline 3. & Purwodadi & 1.758 & 1,13 & $1.555,75$ \\
\hline 4. & Karangtengah & 2.708 & 1,46 & $1.854,79$ \\
\hline 5. & Kramat & 2.951 & 1,89 & $1.561,38$ \\
\hline 6. & Sambeng Wetan & 1.298 & 0,96 & $1.352,08$ \\
\hline 7. & Sambeng Kulon & 1.865 & 1,59 & $1.172,96$ \\
\hline 8. & Purbadana & 3.207 & 1,06 & $3.025,47$ \\
\hline 9. & Kembaran & 5.584 & 1,67 & $3.343,71$ \\
\hline 10. & Bojongsari & 7.566 & 1,64 & $4.613,41$ \\
\hline 11. & Karangsoka & 1.911 & 0,73 & $2.617,81$ \\
\hline 12. & Dukuh Waluh & 10.395 & 2,15 & $4.834,88$ \\
\hline 13. & Tambaksari & 4.188 & 1,46 & $2.868,49$ \\
& Kidul & & & $3.368,22$ \\
\hline 14. & Bantarwuni & 3.604 & 1,07 & $2.988,43$ \\
\hline 15. & Karangsari & 3.616 & 1,21 & $2.519,13$ \\
\hline 16. & Linggasari & 5.794 & 2,30 & $\mathbf{3 . 0 5 4 , 2 4}$ \\
\hline & Jumlah & $\mathbf{7 9 . 1 6 6}$ & $\mathbf{2 5 , 9 2}$ & \\
\hline
\end{tabular}

Sumber: Statistik Daerah Kecamatan Kembaran 2016

Laju pertumbuhan penduduk Kecamatan Kembaran Tahaun 2015 sebesar 1,76 persen. Sex ratio Kecamatan Kembaran adalah sebesar 100,52. Sedangkan rata-rata jumlah anggota rumah tangga setiap rumah tangga adalah 4 orang. Tingkat kepadatan penduduk cukup bervariasi yaitu antara $1.172-6.563$ jiwa per $\mathrm{km}+2$. Desa dengan tingkat kepadatan tertinggi yaitu Desa Ledug dengan tingkat kepadatan mencapai \pm 6.563 jiwa per $\mathrm{km}^{2}$ sedangkan Desa Sambeng Kulon sebagai desa dengan tingkat kepadatan terendah yaitu \pm 1.172 jiwa per $\mathrm{km}^{2}$. Tingkat kepadatan sangat dipengaruhi oleh jumlah penduduk dan luasan wilayah, pada Desa Ledug menunjukkan tingkat kepadatan tinggi dikarenakan jumlah penduduk desa mencapai \pm 14.439 jiwa dan luas desa yang relatif sempit yaitu \pm $2,2 \mathrm{~km}^{2}$.

Perkembangan penduduk yang semakin meningkat salah satunya dipengaruhi oleh kedatangan dan kepindahan penduduk. Pada Tahun 2015 kedatangan penduduk di Kecamatan Kembaran tercatat sebanyak 1.447 orang, sedangkan penduduk yang pindah dari
Kecamatan Kembaran pada Tahun 2015 sebesar 1.254 orang atau sekitar 1,58 persen dari total penduduk yang ada. Selain dipengaruhi kedatangan dan kepindahan penduduk, perkembangan penduduk juga dipengaruhi oleh kelahiran dan kematian. Pada tahun 2015 tercatat kelahiran di Kecamatan Kembaran sebanyak 1.106 bayi. Sedangkan kematian yang tercatat pada Tahun 2014 sebanyak 579 orang.

Sedangkan dominasi pekerjaan penduduk 15 tahun keatas di Kecamatan Kembaran adalah sebagai petani, bidang industri, konstruksi, listrik, gas dan air, serta pertambangan dan penggalian, secara rinci ditampilkan pada Tabel 4 jumlah penduduk 15 tahun keatas menurut lapangan pekerjaan perdesa di Kecamatan Kembaran Tahun 2015. Desa dengan penduduk paling banyak bekerja di sektor pertanian adalah Desa Linggasari dengan jumlah 1.359 orang, sektor konstruksi paling banyak di Desa Ledug sebesar 768 orang, desa dengan jumlah pekerja terbanyak di sektor industri adalah Desa Pliken dengan jumlah 2.058 orang, sedangkan yang 
banyak bekerja di sektor listrik, gas dan air adalah Desa Ledug dengan jumlah 191 orang serta Desa Pliken juga paling banyak yang bekerja di sektor pertambangan dan penggalian sejumlah 284 orang dibandingkan dengan desa desa yang lainnya di Kecamatan Kembaran.

Tabel 2. Penduduk 15 Tahun Keatas Menurut Lapangan Pekerjaan di Kecamatan Kembaran Tahun 2015

\begin{tabular}{|c|l|r|r|r|r|r|}
\hline No. & \multicolumn{1}{|c|}{ Desa } & Pertanian & $\begin{array}{c}\text { Pertambangan dan } \\
\text { Penggalian }\end{array}$ & Industri & $\begin{array}{c}\text { Listrik, Gas } \\
\text { dan Air }\end{array}$ & Konstruksi \\
\hline 1. & Ledug & 694 & 284 & 825 & 191 & 768 \\
\hline 2. & Pliken & 814 & 11 & 2.058 & 102 & 283 \\
\hline 3. & Purwodadi & 455 & 3 & 281 & 13 & 58 \\
\hline 4. & Karangtengah & 804 & 65 & 217 & 16 & 164 \\
\hline 5. & Kramat & 1.250 & 6 & 150 & 14 & 126 \\
\hline 6. & Sambeng Wetan & 504 & 8 & 121 & 3 & 98 \\
\hline 7. & Sambeng Kulon & 561 & 27 & 204 & 3 & 173 \\
\hline 8. & Purbadana & 712 & 5 & 127 & 50 & 93 \\
\hline 9. & Kembaran & 827 & 39 & 541 & 34 & 390 \\
\hline 10. & Bojongsari & 911 & 67 & 645 & 106 & 522 \\
\hline 11. & Karangsoka & 196 & 73 & 236 & 74 & 126 \\
\hline 12. & Dukuh Waluh & 726 & 6 & 426 & 155 & 785 \\
\hline 13. & Tambaksari Kidul & 450 & 8 & 500 & 173 & 336 \\
\hline 14. & Bantarwuni & 460 & 10 & 419 & 62 & 340 \\
\hline 15. & Karangsari & 381 & 3 & 753 & $\mathbf{2 8}$ & 326 \\
\hline 16. & Linggasari & 1.359 & $\mathbf{6 2 2}$ & $\mathbf{8 . 0 6 6}$ & $\mathbf{1 . 1 1 2}$ & 482 \\
\hline & Jumlah & $\mathbf{1 1 . 1 0 4}$ & $\mathbf{5 . 0 7 0}$ \\
\hline
\end{tabular}

Sumber: Kecamatan Kembaran Dalam Angka 2016

\section{Analisis Dominasi Penggunaan Lahan Kekotaan Dan Kedesaan Di Kecamatan Kembaran}

Dominasi penggunaan lahan kekotaan dan kedesaan pada masingmasing desa Kecamatan Kembaran akan dijabarkan satu persatu, namun perlu dipahami terlebih dahulu makna dari penggunaan lahan kekotaan. Menurut Yunus (2000) penggunaan lahan kekotaan adalah bangunan/permukiman atau terkait dengan kegiatan industri dan permukiman, sedangkan penggunaan lahan kedesaan adalah sawah, kebun, tegalan atau terkait dengan kegiatan pertanian.

Dengan demikian dari pengertian Yunus (2000) tersebut dominasi penggunaan lahan kekotaan dan kedesaan di desa-desa Kecamatan Kembaran dapat diidentifikasi dari Tabulasi Penggunaan Lahan Kecamatan Kembaran pada Peta Gambar 5.

Penggunaan lahan di Kecamatan Kembaran didominasi oleh Lahan Sawah dengan $66,03 \%$, 30,93\% digunakan untuk Permukiman, 1,73\% digunakan untuk Kebun, 0,89\% digunakan untuk Tegalan sebesar 0,89\% dan Rumput/Tanah Kosong sebesar $0,42 \%$ dari luas wilayah kecamatan, dimana penggunaan lahan sawah paling luas berada di Desa Pliken seluas 186,03 hektar, untuk permukiman terluas di Desa Ledug dengan 126,55 hektar, kebun terluas di Desa Purbadana dengan 8,40 hektar, tegalan terluas di Desa Pliken dengan 12,33 hektar, dan penggunaan rumput/tanah kosong terluas berada di Desa Ledug dengan luas 3,45 hektar. 


\section{Jurnal \\ JSSH}

Lebih dijabarkan secara rincian hasil tabulasi Peta Penggunaan Lahan di Kecamatan Kembaran luasan lahan kekotaan dan kedesaan pada Tabel 3 untuk 16 desa secara keseluruhan. Sedangkan secara khusus pembahasan mengenai penggunaan lahan kekotaan dan kedesaan pada desa-desa sampel dijabarkan sebagai berikut:

a. Desa Dukuh Waluh,

merupakan desa yang memiliki penggunaan lahan kekotaan terluas di Kecmatan Kembaran dengan luasan 74,38 Hektar atau berkisar 48,06\% dari luas wilayah Desa Dukuh Waluh 154.76
Hektar, desa ini mengalami peningkatan penggunaan lahan kekotaan yang lebih cepat disebabkan keberadaan beberapa perguruan tinggi yang ada diwilayah ini, seperti Universitas Muhammadiyah Purwokerto dan Harapan Bangsa, sehingga kemudian kondisi tersebut semakin memunculkan fasilitas pendukung lainnya seperti pertokoan, rumah makan, kos-kosan, fotokopi dan fasilitas umum lainnya. Adapun salah satu contoh kondisi lahan kekotaan yang ada di Desa Dukuh Waluh ditampilkan pada Gambar 2.

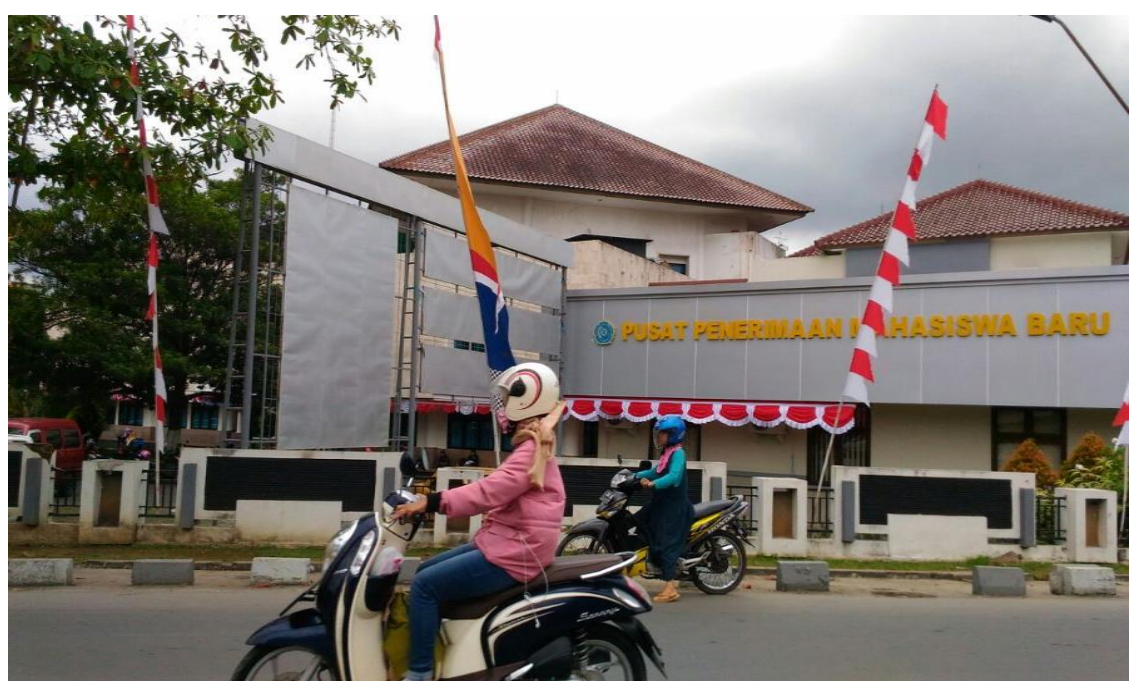

Gambar 2. Infrastruktur Berciri Kekotaan di Desa Dukuh Waluh (Sumber: Data Lapangan, 2017)

b. Desa Sambeng Kulon,

Merupakan desa yang memiliki penggunaan lahan kedesaan terluas di Kecmatan Kembaran dengan luasan 172,26 Hektar atau berkisar 83,71\% dari luas wilayah Desa Sambeng Kulon 205.79 Hektar, desa ini merupakan desa yang terletak dibagian paling timur dari Kecamatan Kembaran dan memiliki jarak yang cukup jauh dari kekotaan, sehingga hal ini dapat meyakinkan bahwa pengaruh perkembangan penggunaan lahan kekotaan tidak terlalu berkembang di Desa Sambeng Kulon.

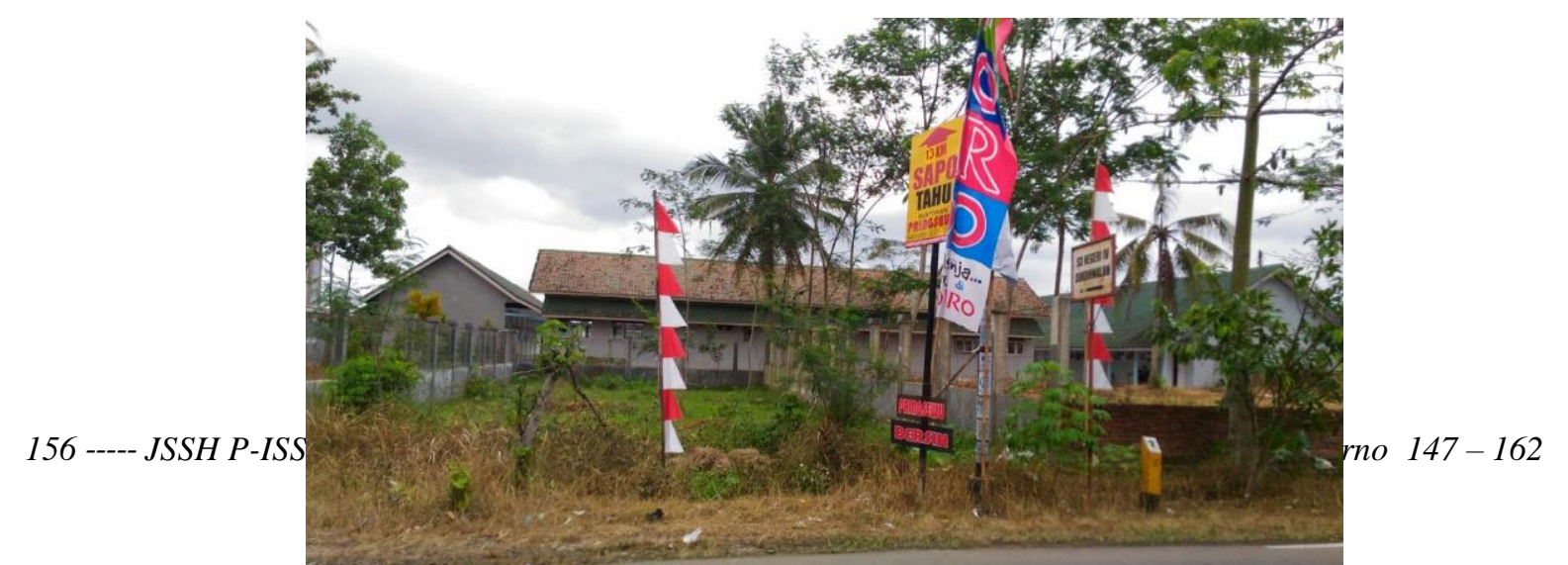


Gambar 3. Lahan Tidur (Sumber: Data Lapangan, 2017)

c. Desa Kembaran

Merupakan desa yang berada dibagian pertengahan dari Kecamatan Kembaran, terletak diantara Desa Dukuh Waluh (2 Km kearah Timur) dan Desa Sambeng Kulon $(1.9 \mathrm{Km}$ ke arah Barat). Desa ini menampakkan penggunaan lahan dengan dominasi kekotaan sebesar $47.49 \%$ dari luasan wilayahnya atau sebesar 72.08 Hektar lahan kekotaan dari 151.76 Hektar dan $52.51 \%$ penggunaan lahan kedesaan atau berkisar 79.69 Hektar. Dominasi lahan kekotaan yang hamper seimbang dengan dominasi kedesaan ini diperkirakan akibat Desa kembaran merupakan pusat ibu kota Kecamatan Kembaran, sehingga pemekaran terhadap penggunaan lahan kekotaan menunjukkan arah yang semakin meluas pada tahun 2011 dibandingkan pada tahun 2002, hal ini diungkapkan dalam penelitian Sutomo dan Sakinah (2014)

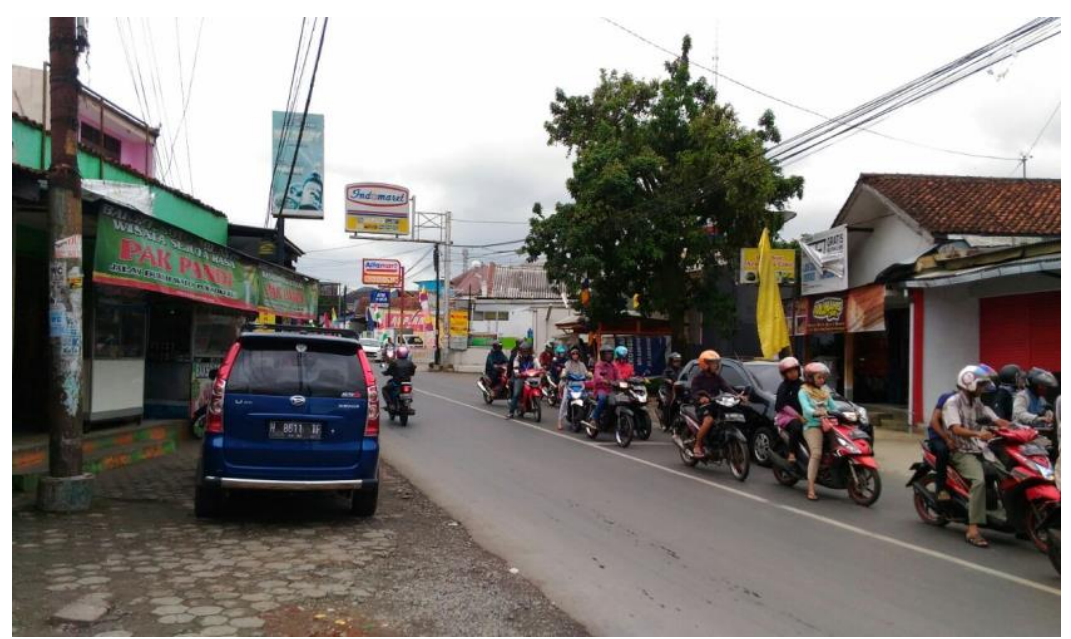

Gambar 4. Pertokoan dan Rumah Makan

(Sumber: Data Lapangan, 2017)

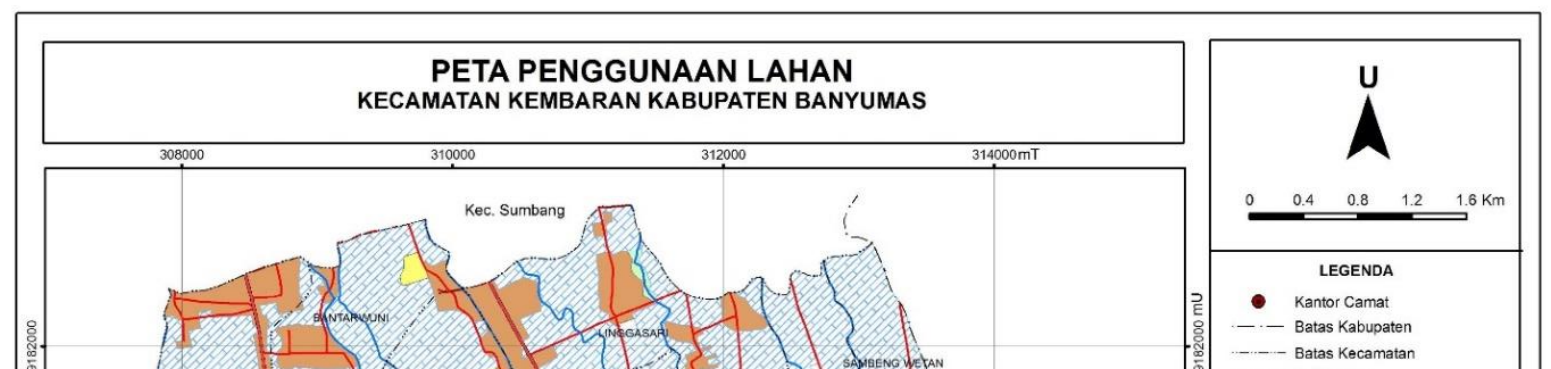


Gambar 5. Peta Penggunaan Lahan Kecamatan Kembaran Kabupaten Banyumas

\begin{tabular}{|c|c|c|c|c|c|c|c|}
\hline No. & Desa & $\begin{array}{c}\text { Penggunaan } \\
\text { Lahan }\end{array}$ & $\begin{array}{c}\text { Luas } \\
\text { Ha }\end{array}$ & $\begin{array}{c}\text { Luas } \\
\text { Penggunaan } \\
\text { Lahan } \\
\text { Kekotaan } \\
\text { (Ha) } \\
\end{array}$ & $\begin{array}{c}\text { Persentase } \\
\text { Penggunaan } \\
\text { Lahan } \\
\text { Kekotaan } \\
\end{array}$ & $\begin{array}{c}\text { Luas } \\
\text { Penggunaan } \\
\text { Lahan } \\
\text { Kedesaan } \\
\text { (Ha) } \\
\end{array}$ & $\begin{array}{c}\text { Persentase } \\
\text { Penggunaan } \\
\text { Lahan } \\
\text { Kedesaan } \\
\end{array}$ \\
\hline \multirow{6}{*}{1} & \multirow{5}{*}{ Pliken } & Kebun & 7.43 & \multirow{5}{*}{80.55} & \multirow{5}{*}{$27.98 \%$} & \multirow{5}{*}{207.37} & \multirow{5}{*}{$72.02 \%$} \\
\hline & & Pemukiman & 80.55 & & & & \\
\hline & & $\begin{array}{l}\text { Rumput/Tanah } \\
\text { kosong }\end{array}$ & 1.59 & & & & \\
\hline & & Sawah & 186.03 & & & & \\
\hline & & Tegalan & 12.33 & & & & \\
\hline & \multicolumn{2}{|c|}{ Luas Wilayah Pliken } & 287.91 & & & & \\
\hline \multirow{4}{*}{2} & \multirow{3}{*}{ Ledug } & Pemukiman & 126.55 & \multirow{3}{*}{126.55} & \multirow{3}{*}{$\mathbf{4 7 . 8 8 \%}$} & \multirow{3}{*}{137.78} & \multirow{3}{*}{$52.12 \%$} \\
\hline & & $\begin{array}{l}\text { Rumput/Tanah } \\
\text { kosong }\end{array}$ & 3.45 & & & & \\
\hline & & Sawah & 134.33 & & & & \\
\hline & \multicolumn{2}{|c|}{ Luas Wilayah Ledug } & 264.33 & & & & \\
\hline \multirow{4}{*}{3} & \multirow{3}{*}{$\begin{array}{l}\text { Karangtengah } \\
\text { Kidul }\end{array}$} & Pemukiman & 51.93 & \multirow{3}{*}{51.93} & \multirow{3}{*}{$23.51 \%$} & \multirow{3}{*}{168.97} & \multirow{3}{*}{$76.49 \%$} \\
\hline & & $\begin{array}{l}\text { Rumput/Tanah } \\
\text { kosong }\end{array}$ & 0.48 & & & & \\
\hline & & Sawah & 168.49 & & & & \\
\hline & \multicolumn{2}{|c|}{$\begin{array}{l}\text { Luas Wilayah Karangtengah } \\
\text { Kidul }\end{array}$} & 220.90 & & & & \\
\hline \multirow{4}{*}{4} & \multirow{3}{*}{ Purwodadi } & Kebun & 4.34 & \multirow{3}{*}{29.70} & \multirow{3}{*}{$19.76 \%$} & \multirow{3}{*}{120.61} & \multirow{3}{*}{$80.24 \%$} \\
\hline & & Pemukiman & 29.70 & & & & \\
\hline & & Sawah & 116.27 & & & & \\
\hline & \multicolumn{2}{|c|}{ Luas Wilayah Purwodadi } & 150.31 & & & & \\
\hline \multirow{4}{*}{5} & & Pemukiman & 48.83 & \multirow{3}{*}{48.83} & \multirow{3}{*}{$31.04 \%$} & \multirow{3}{*}{108.51} & \multirow{3}{*}{$68.96 \%$} \\
\hline & Bojongsari & $\begin{array}{l}\text { Rumput/Tanah } \\
\text { kosong }\end{array}$ & 1.61 & & & & \\
\hline & & Sawah & 106.90 & & & & \\
\hline & Luas Wilayah & Bojongsari & 157.35 & & & & \\
\hline 6 & Kramat & Kebun & 7.24 & 34.44 & $24.17 \%$ & 108.07 & $75.83 \%$ \\
\hline
\end{tabular}




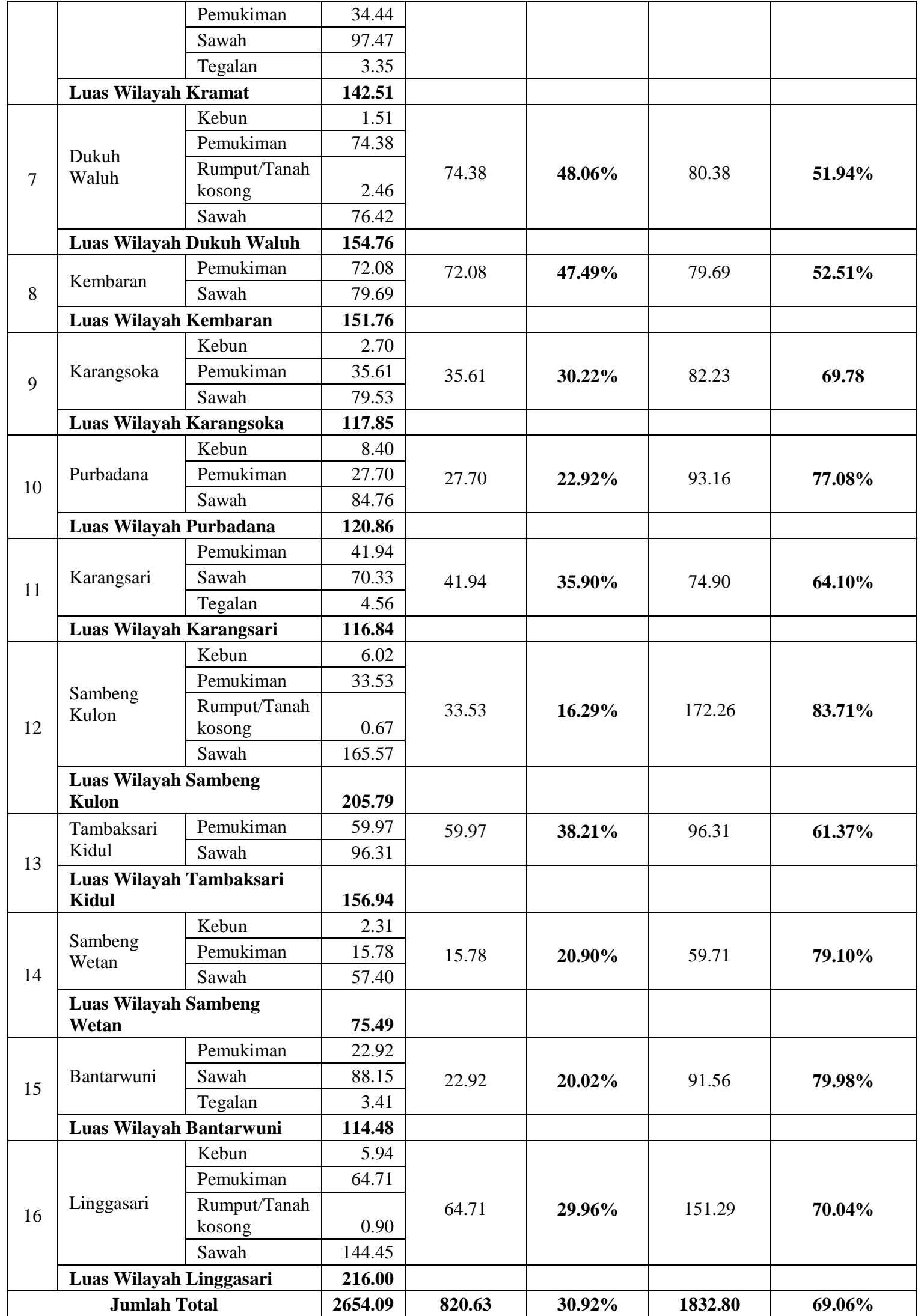

Tabel 3. Luasan Penggunaan Lahan Kekotaan dan Kedesaan di Desa-Desa Kecamatan Kembaran

3. Analisis kategori desa-desa di Kecamatan Kembaran dalam ketentuan subzone Urban/Ural/Rural menurut Yunus (2000). 
Setelah diketahui penggunaan lahan yang mendominasi pada desa-desa sampel penelitian dalam bentuk persentase penggunaan lahan kekotaan dan kedesaan, selanjutnya masing-masing desa sampel diklasifikasikan apakah termasuk Urban/Urral ataukah Rural menurut Yunus (2000) dalam Model Segitiga Penggunaan Lahan Desa-Kota.

Namun sebelum menentukan desa-desa sampel dalam subzone Urban/Ural/Rural menurut Yunus (2000) dari data persentase dominasi penggunaan lahan kekotaan dan kedesaan, perlu data tambahan berupa jarak drai daerah Kota Purwokerto ke desa-desa di kecamatan Kembaran, Kota Purwokerto merupakan kota yang terbentuk di Kabupaten Banyumas dan terletak disebelah barat dari Kecamatan Kembaran, adapun data tersebut tertuang dalam Tabel 4 berikut ini.

Tabel 4. Jarak dari Daerah Kota Purwokerto ke Desa-Desa Kecamatan Kembaran

\begin{tabular}{|c|l|r|r|}
\hline No. & \multicolumn{1}{|c|}{ Desa } & \multicolumn{1}{c|}{ Jarak (Km) } & \multicolumn{1}{c|}{ Persentase Jarak (\%) } \\
\hline 1. & Pliken & 0.3 & 4.01 \\
\hline 2. & Ledug & 3.1 & 0.75 \\
\hline 3. & Karangtengah Kidul & 3.5 & 7.77 \\
\hline 4. & Purwodadi & 3.1 & 8.77 \\
\hline 5. & Bojongsari & 4.8 & 7.77 \\
\hline 6. & Kramat & 0.6 & 12.03 \\
\hline 7. & Dukuh Waluh & 2.2 & 1.50 \\
\hline 8. & Kembaran & 1.6 & 5.51 \\
\hline 9. & Karangsoka & 3.3 & 4.01 \\
\hline 10. & Purbadana & 2.4 & 8.27 \\
\hline 11. & Karangsari & 3.4 & 6.02 \\
\hline 12. & Sambeng Kulon & 0.6 & 8.52 \\
\hline 13. & Tambaksari Kidul & 5.1 & 1.50 \\
\hline 14. & Sambeng Wetan & 1.4 & 12.78 \\
\hline 15. & Bantarwuni & 2.9 & 3.51 \\
\hline 16. & Linggasari & $\mathbf{3 9 . 9 0}$ & 7.27 \\
\hline & Jumlah & $\mathbf{1 0 0 . 0 0}$ \\
\hline
\end{tabular}

\section{Sumber: Peta Digital Rupa Bumi Indonesia, 2017}

Setelah diketahui jarak dari daerah kota ke desa-desa, dan dominasi penggunaan lahan kekotaan dan kedesaan, maka desa desa sampel dapat dimasukkan pada subzone Urban/Ural/Rural menurut Yunus (2000), penjelasan sebagai berikut: a. Desa Dukuh Waluh

Desa ini memiliki persentase $\mathbf{1 . 5 0 \%}$ jarak dari daerah Kota Purwokerto ke Desa Dukuh Waluh, sedangkan persentase lahan kekotaan sebesar 48.06\% dan persentase lahan kedesaan sebesar 51.94\%, maka termasuk dalam subzone Urban Fringe.

b. Desa Sambeng Kulon

Desa ini memiliki persentase jarak dari daerah Kota Purwokerto ke Desa
Sambeng Kulon 8.52\%, presentase lahan kekotaan $\mathbf{1 6 . 2 9 \%}$ dan presentase lahan kedesaan 83.71\%, maka termasuk dalam subzone Urban Fringe.

c. Desa Kembaran

Memiliki persentase jarak dari daerah Kota Purwokerto ke Desa Kembaran $\mathbf{5 . 5 1 \%}$, presentase lahan kekotaan $\mathbf{4 7 . 4 9 \%}$ dan presentase lahan kedesaan $\mathbf{5 2 . 5 1 \%}$, maka termasuk dalam subzone Urban Fringe.

Setelah dimasukkan pada model segitiga penggunaan lahan Desa-Kota ketiga desa sampel menunjukkan terletak pada subzone Urban Fringe, yang berarti ke tiga desa tersebut merupakan bagian yang tidak terlepas pengaruhnya dari Kota Purwokerto, 
dikarenakan jarak yang cukup dekat, sehingga pengaruh Kota akan berefek cukup signifikan kepada ketiga desa tersebut.

\section{KESIMPULAN DAN SARAN}

\section{Kesimpulan}

a. Dominasi penggunaan lahan kekotaan dan kedesaan di Kecamatan Kembaran menunjukkan bahwa terdapat desa dengan dominasi penggunaan lahan kekotaan mencapai $48.06 \%$ dari luas wilayah desanya,, yaitu Desa Dukuh Waluh, namun ada pula desa dengan penggunaan lahan kekotaan $16.29 \%$ dari luas wilayah desanya yaitu Desa Sambeng Kulon.

b. Sedangkan dari hasil meninjau persentase penggunaan lahan kekotaan dan kedesaan sekaligus persentase jarak dari daerah Kota Purwokerto ke desa-desa di Kecamatan Kembaran, maka menurut Model Segitiga Penggunaan Lahan DesaKota masuk pada subzone Urban Fringe.

\section{Saran}

Perlunya peran dan sinergitas antara masyarakat, pemerintah dan akademisi dalam penataan ruang khususnya penggunaan lahan sehingga kemanfaatan dan keberlanjutan dari sebuah wilayah dapat terus-menerus dipertahankan sesuai dengan daya dukung yang dimiliki wilayah tersebut.

\section{DAFTAR PUSTAKA}

[1] Badan Pusat Statistik Kabupaten Banyumas. 2016. Kecamatan Kembaran dalam Angka.

[2] Badan Pusat Statistik Kabupaten Banyumas. 2016. Statistik Daerah Kecamatan Kembaran 2016. Katalog BPS: 1101002.3302220 .

[3] Bintaro. 1989. Dalam Interaksi DesaKota dan Permasalahannya. Jakarta: Ghalia Indonesia.

[4] Kamus Besar Bahasa Indonesia. 2013. Hlm.2. Medan: Bitra Indonesia.

[5] Malingreau, Jean Paul. 1977. Apropose Land Cover/ Land use Classification and its use With remote Sensing Data In
Indonesia. The Indonesian journal of Geography. No.33 Vol 7. Yogyakarta: Fakultas Geografi UGM.

[6] Muta'ali, Lutfi. 2013. Penataan Ruang Wilayah dan Kota (Tinjauan NormatifTeknis). Jogjakarta: Badan Penerbit Fakultas Geografi Universitas Gadjah Mada.

[7] Muta'ali, Lutfi. 2013. Pengembangan Wilayah Perdesaan. Jogjakarta: Badan Penerbit Fakultas Geografi Universitas Gadjah Mada.

[8] Peraturan Pemerintah Nomor 72 Tahun 2005 Tentang Desa.

[9] Rakhman, Adib Zakia. 2013. Kajian Perubahan Penggunaan Lahan di Desa Sokaraja Kulon Kecamatan Sokaraja Kabupaten Banyumas Tahun 2001 dan 2011. Skripsi. Universitas Muhammadiyah Purwokerto.

[10] Shalihati, Sakinah F dan Esti. 2015. Analisis Persebaran Masjid Sarana Pengajian Ahad Pagi Muhammadiyah Kabupaten Purbalingga. Prosiding HasilHasil Penelitian dan Pengabdian LPPM UMP. Purwokerto: UMP Press.

[11] Sutomo. 2001. Faktor-Faktor yang Mempengaruhi Perkembangan Fisikal Kawasan Koridor antara Kota Purwokerto-Sokaraja. Tesis. Universitas Gadjah Mada.

[12] Sutomo dan Sakinah F Shalihati. 2013. Kajian Kemiskinan dan Perkembangan Wilayah Kabupaten Purbalingga dalam Perspektif Geospatial. Jurnal Geoedukasi Vol IV Nomor 1 Maret 2015. Pendidikan Geografi Universitas Muhammadiyah Purwokerto.

[13] Sutomo dan Sakinah F Shalihati. 2014. Transformasi Wilayah di Koridor Purwokerto-Purbalingga. Prosiding Seminar Hasil Penelitian LPPM UMP 2014. Purwokerto: UMP Press.

[14] Sutomo dan Sakinah F Shalihati. 2015. Analisis Infrastruktur Unggulan Dalam Perkembangan Wilayah Kecamatan 
Purbalingga. Prosiding Hasil-Hasil

Penelitian dan Pengabdian LPPM UMP. Purwokerto: UMP Press.

[15] Undang-Undang Republik Indonesia Nomor 26 Tahun 2007 Tentang Penataan Ruang

[16] Undang-Undang Republik Indonesia Nomor 4 tahun 2011 Tentang Informasi Geospasial.
[17] Yunus, Hadi Sabari. 1978. Interaksi Desa dan Kota.Yogyakarta: Liberty.

[18] Yunus, Hadi Sabari. 1994. Teori dan Model Struktur Keruangan Kota. Fakultas Geografi UGM. Yogyakarta.

[19] Yunus, Hadi Sabari. 2000. Struktur Tata Ruang Kota. Jogjakarta: Pustaka Pelajar 


\section{Jurnal}

JSSH SAINS SOSIAL dan HUMANIORA 